Georgetown University Law Center

Scholarship @ GEORGETOWN LAW

2008

From Snail Mail to E-Mail: The Traditional Legal Memorandum in the Twenty-First Century

Kristen Konrad Robbins-Tiscione

Georgetown University Law Center, kkt@law.georgetown.edu

This paper can be downloaded free of charge from:

https://scholarship.law.georgetown.edu/facpub/798

http://ssrn.com/abstract=1268946

58 J. Legal Educ. 32-60 (2008)

This open-access article is brought to you by the Georgetown Law Library. Posted with permission of the author. Follow this and additional works at: https://scholarship.law.georgetown.edu/facpub

Part of the Legal Education Commons, and the Legal Writing and Research Commons 


\title{
From Snail Mail to E-Mail: The Traditional Legal Memorandum in the Twenty-First Century
}

\author{
Kristen Konrad Robbins-Tiscione
}

Traditional legal memoranda have been used to teach objective analysis since the inception of legal writing programs in the r97os. The continued use of these memoranda in the legal writing classroom leads law students to believe that traditional memoranda are still a primary form of communication between attorney and client. A 2006 survey of Georgetown University Law Center graduates, however, suggests that the traditional legal memorandum ${ }^{\mathrm{r}}$ is all but dead in law practice. As might be expected, the more senior the practitioner, the fewer memoranda she is likely to write. ${ }^{2}$ Nevertheless, a majority of the most recent graduates surveyed -62 percent-said they write either no traditional memoranda at all or just one to three per year. Out of I40 total responses, 57 practitioners surveyed from the classes of 1983 , 1988, 1993, 1998, and 2003 said they write no memoranda at all, and forty-one said they write one to three per year. As Figure I below illustrates, that means 75 percent of the respondents write no more than three traditional memoranda per year. No more than three. Instead, the survey indicates, these graduates are far more likely to communicate with clients about their research results by e-mail, telephone, face-to-face discussion, informal memorandum, or a letter, and in that order of preference. Ninety-two percent of all graduates surveyed said that they use substantive e-mail to communicate with their clients. ${ }^{3}$ In fact, on a scale of one

Kristen Tiscione, a former litigator at Kirkland \& Ellis, has taught legal research and writing courses at Georgetown University Law Center since r994. Her scholarly interest lies in classical and contemporary rhetorical theory and its relation to legal argument.

I. The term here refers to a formal written memorandum that used to be sent through the mail to clients, usually containing a prescribed number and order of elements: a question presented or issue, brief answer or summary of analysis, statement of facts, discussion or analysis, and conclusion.

2. Sixty-seven percent of Georgetown's 1983 graduates report that they write no traditional memoranda, and 26 percent write just one to three a year. In contrast, only 27 percent of 2003 graduates report writing no traditional memoranda, and 35 percent write one to three per year.

3. Substantive e-mail as used in this article means e-mail that contains legal analysis and/ or advice in the body of the message as opposed to in an attached formal or informal memorandum.

Journal of Legal Education, Volume 58 , Number I (March 2008) 
to eight, substantive e-mail ranks first as the graduates' method of choice for communicating with clients.

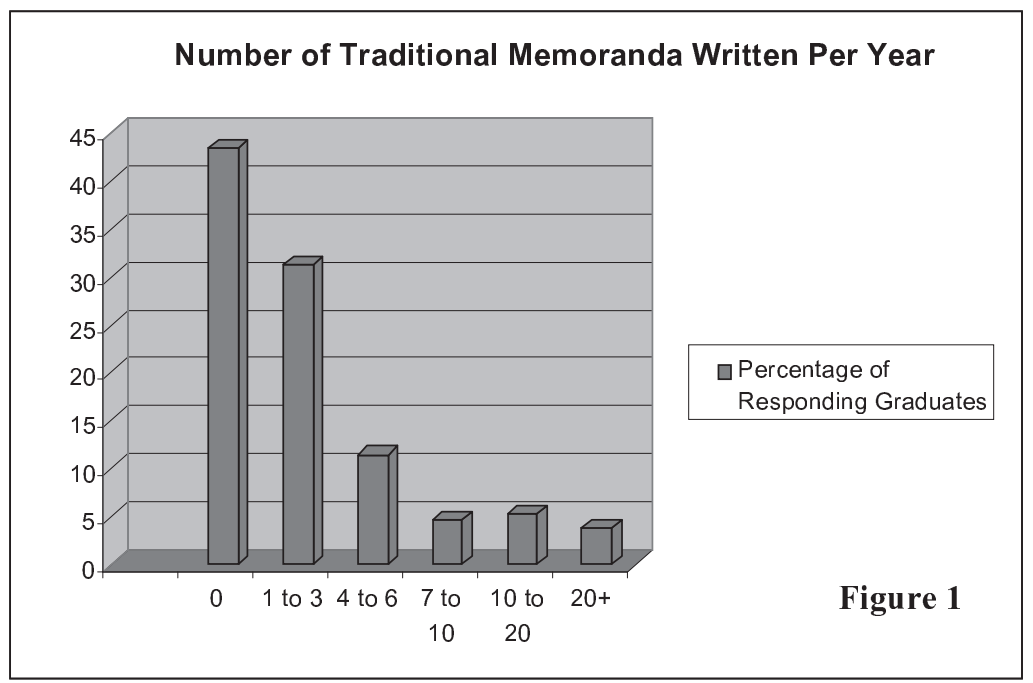

Although the survey indicates that graduates are divided when it comes to using traditional memoranda to teach legal analysis per se, they uniformly agree that the traditional memorandum is only somewhat helpful in making the transition from law school to law practice. An overwhelming majority of Georgetown's 2003 graduates-93 percent-indicated that writing informal memoranda in law school would have been more useful. Although 63 percent of 1983 graduates said learning to write client letters would have been more useful, they are likely influenced by the fact that, as more senior attorneys, they are more likely to draft opinion or advice letters directly to clients. As for substantive e-mail, the formats currently being used by all graduates seem to vary, but they approximate an informal memorandum, which includes a statement of the legal issue and the attorney's conclusion or advice, followed by supporting analysis. Whereas the elements of the traditional legal memorandum are static, the elements of the informal memorandum and substantive e-mail appear to be organic, determined by the nature of the question at issue, as opposed to a prescribed set of elements.

Despite its infrequent use, the traditional legal memorandum still seems to be the most popular format used to teach objective legal analysis in legal research and writing (LRW) programs. ${ }^{4}$ To the extent the survey results apply to legal practice at large, they are noteworthy, particularly because even the most recently published books in the legal writing field use the

4. See Association of Legal Writing Directors and Legal Writing Institute, 2006 Survey Results I2 (2006), available at <http://lwionline.org/survey/surveyresults2oo6.pdf> (last visited June 26,2008$)$. According to this annual survey, I 82 of the $I_{4} 4$ responding schools use office memoranda for teaching objective writing, compared to just Ioo schools that use client letters in addition to formal memoranda to teach this form of analysis. Id. 
memorandum as the paradigm of objective analysis, without acknowledging its near obsolescence. ${ }^{5}$ Although the traditional memorandum may be a perfectly good tool for teaching legal analysis, LRW faculty should inform students that traditional memoranda are used rarely and informal memoranda and substantive e-mails are supplanting them. If LRW faculty do not acknowledge the role these modes of communication play in practice, they risk misleading students into believing they will communicate with colleagues and clients primarily through traditional memoranda. To the contrary, the survey suggests that attorneys are using e-mail to practice law in new ways that reflect their clients' growing demands for quick response time and simple, straightforward advice. At the least, the growing use of informal memoranda and substantive e-mail should be acknowledged by and perhaps even incorporated into LRW programs. As several Georgetown graduates indicated, the risks unique to this method of communication also need to be addressed. In these graduates' experience, attorneys tend to be less careful with phrasing and proofing e-mail than other forms of writing, and the ease with which e-mail can be redistributed jeopardizes attorneyclient privilege and confidentiality.

\section{The Goals, Design, and Results of the Survey}

The survey sought to determine the current methods used to communicate with and advise clients and to explore the ramifications for LRW curricula. If the traditional memorandum taught to students no longer reflects reality, then LRW programs are not fulfilling their primary mission to prepare students for the world of legal practice. By adhering to the traditional format without regard to its declining use, LRW faculty may embarrass their students who will not know that the traditional memorandum is rarely used today. Moreover, they elevate form over substance, much as the nineteenth century modes of discourse elevated types of writing over purpose and eventually fell into disfavor. ${ }^{6}$ In the late nineteenth century, composition textbooks adopted the four modes of discourse-narration, exposition, description, and argument-as the method for teaching students to write. ${ }^{7}$ These categories were convenient because they focused on end products, but they led students to believe that

5. See, e.g., John C. Dernbach et al., A Practical Guide to Legal Writing \& Legal Method (3d ed., New York, 2007); Linda H. Edwards, Legal Writing and Analysis 127-4I (2d ed., New York, 2007); Elizabeth Fajans, Mary R. Falk, and Helene S. Shapo, Writing for Law Practice 254-78 (New York, 2004); Richard K. Neumann, Legal Reasoning and Legal Writing: Structure, Strategy and Style 73-78 (5th ed., New York, 2005); Laurel C. Oates and Anne Enquist, Just Memos 39-50 (2d ed., New York, 2006).

6. See, e.g., Robert J. Connors, The Rise and Fall of the Modes of Discourse, 32 CCC 444 (December 198I), reprinted in The Writing Teacher's Sourcebook 24 (Gary Tate and Edward P.J. Corbett eds., 2d ed., Oxford, I988). See also James L. Kinneavy, A Theory of Discourse: The Aims of Discourse 28-30 (New York, I971).

7. The first three types were conceived of as "inform[ing] the understanding," whereas argument was considered "the means of influencing the will." Connors, The Rise and Fall of the Modes of Discourse, supra note 6, at 25. 
writing is essentially a mechanical process. By focusing on what to write instead of how to write, the modes

represent $[\mathrm{ed}]$ an unrealistic view of the writing process, a view that assumes writing is done by formula and in a social vacuum. They turn the attention of both teacher and student toward an academic exercise instead of toward a meaningful act of communication in a social context. ${ }^{8}$

Similarly, blind adherence to an outdated memorandum format ignores the context and manner in which attorneys actually write. More importantly, it ignores the multiple purposes for which attorneys give written advice and the extent to which informal memoranda and e-mail allow the nature of the legal problem to shape their mode of analysis. Although well-established, the traditional memorandum is not in itself a purpose for writing, and it should give way to a more purpose-driven approach to teaching written analysis.

The survey consisted of twenty-four questions, divided into two major sections. The first section asked graduates from the classes of $198_{3}, 1988$, I993, I998, and 2003 to identify their graduating class and explain the nature of their employment and law practice, including the size of their office. The second section asked whether they use traditional legal memoranda, why or why not, and how often. It also sought their advice on how best to teach objective legal analysis and what documents they think should be included in a first-year LRW course. Finally, the second section asked graduates what methods of communication they typically use to communicate with clients and which methods they use most often. ${ }^{9}$ E-mails were sent to all graduates from these classes with known e-mail addresses, which provided them with a link to the survey and an invitation to participate. Roughly 424 e-mails were sent and received, and 33 percent of the graduates responded, for a total of I40 responses. With the exception of the class of 1998 , each of the classes is represented nearly equally, with 24 to 28 responses. ${ }^{\text {IO }}$ The class of $1998 \mathrm{had}$ a total of 34 responses. Sixty-nine percent of the respondents are practicing in a private law firm, with litigation as the highest area of practice (47 percent) and business law a distant second (26 percent). ${ }^{\text {II }}$ Responses from litigators versus non-litigators were surprisingly similar with regard to overall results. The largest number of respondents was practicing in private firms in excess of 200 attorneys. ${ }^{12}$ As discussed in detail below, three main themes emerge from the survey data.

8. Id. at 33 (quoting Albert Kitzhaber, Rhetoric in American Colleges, I850-190o (Dallas, I990).

9. A copy of the survey questions and the aggregate responses of all I40 participants is attached as Appendix I, at 5 I. Reports of responses by class or practice area are available on request.

Io. See Appendix I, Question I, at $5^{\mathrm{I}}$.

II. Id. at Questions 4 and 5 , at $5^{\mathrm{I}}$.

I2. Id. at Question 6, at 52 . 
The Traditional Legal Memorandum May Be Obsolete in Legal Education As Well As Practice

As Figure I shows, 75 percent of the responding graduates write no more than three traditional memoranda per year. ${ }^{13}$ Roughly 12 percent write four to six, 5 percent write seven to ten, 5 percent write ten to twenty, and 4 percent write more than twenty. ${ }^{14}$ Surprisingly, the majority of clients do not always or even usually discourage drafting these memoranda, at least directly, although clients sometimes do. (See Figure 2.) When clients discourage the preparation of traditional memoranda, the principal reason is cost. As Figure 3 illustrates, the graduates said that in addition to being quite costly, drafting traditional memoranda is not useful and/or an efficient use of their time because it is easier to draft the document the memorandum often anticipates.
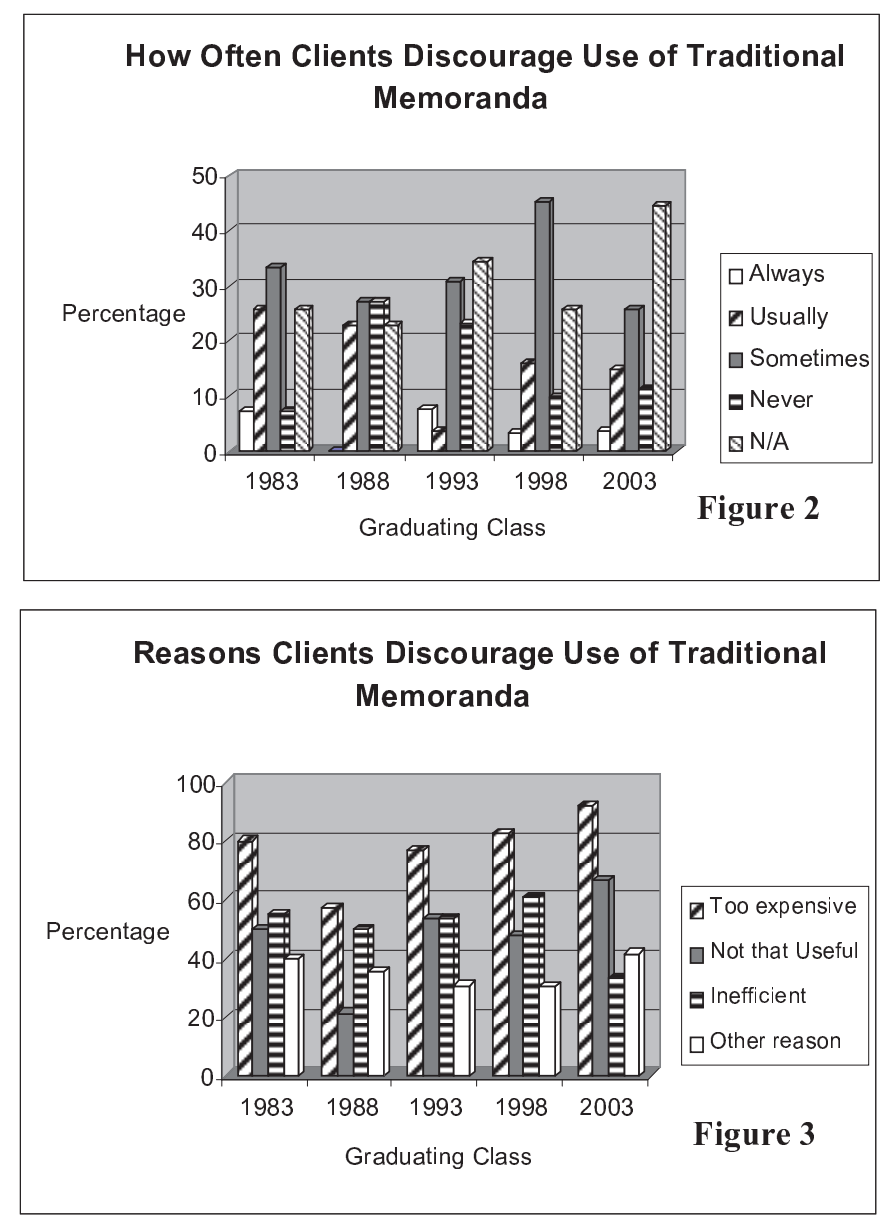

I3. See Figure I, at 33 .

I4. Id. 
In response to Question 9, which asked how helpful learning to write traditional memoranda was "in terms of mastering objective legal analysis," the graduates' responses varied. As Figure 4 shows, a large majority of graduates-ranging from 75 to 8I percent-from the classes of 1983 , I988, I993, and 1998 indicated that writing traditional memoranda in law school was either extremely or very helpful. Respondents from the class of 2003 , however, felt differently; only 59 percent found these memoranda extremely or very helpful. Figure 4 also reveals a growing percentage of graduates for whom writing traditional memoranda was only somewhat helpful-from I 4.8 percent in 1983 to 37 percent in $2003-$ and, for the first time, a small percentage of graduates from the class of 2003 for whom the memoranda was not at all useful ( 3.7 percent).

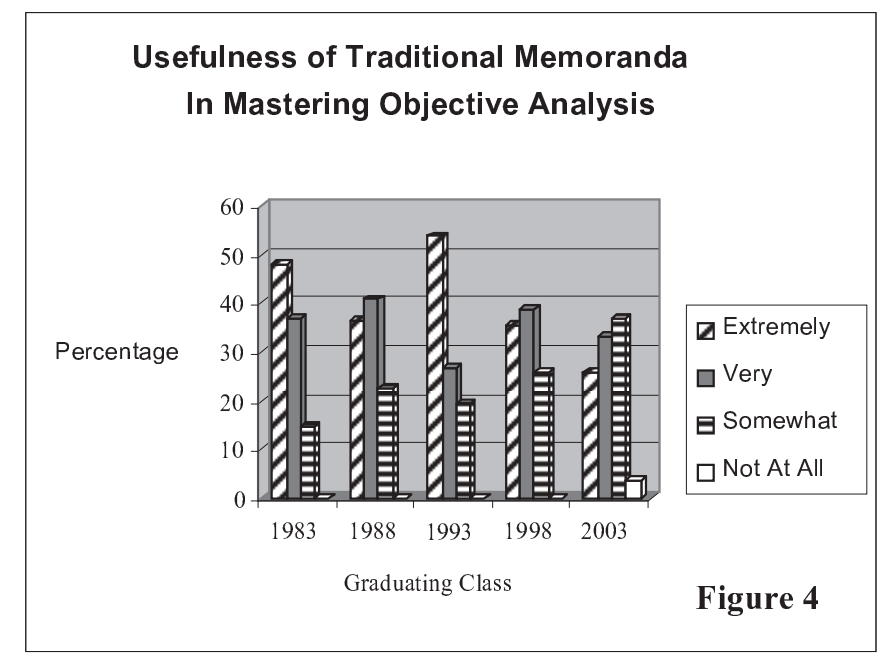

Question Io asked graduates how helpful writing traditional memoranda in law school was in "making the transition from law school to law practice." Overall, the largest number of respondents $-3^{8}$ percent-said that knowing how to write traditional memoranda was only somewhat helpful in practice. Thirty-six percent found it very helpful, 22 percent found it extremely helpful, and 4.5 percent found it not helpful at all. ${ }^{15}$ While this information is itself interesting, when the responses are separated by graduating class, some interesting patterns can be seen. Figure 5 suggests that at some point between 1993 and 1998 , the usefulness of the memoranda for making the transition to law practice changed considerably. The percentage of graduates who found the traditional memoranda either extremely or very helpful increased from 59 percent in 1983 to 77 percent in 1993 . In I998, however, that percentage dropped to 52 percent, and in 2003 it dropped to 37 percent. Similarly, the percentage of graduates who found it only somewhat helpful decreased from 37 percent

I5. See Appendix I, Question Io, at 54 . 
for 1983 graduates to 19 percent for 1993 graduates, and it began to increase as reported by 1998 graduates. Whereas 45 percent of 1998 graduates said the traditional memorandum was only somewhat helpful, a majority of 2003 graduates said it was only somewhat helpful. Eleven percent who graduated in 2003 said it was not helpful at all. Although the reasons for the increase in graduates' satisfaction with the traditional memoranda from 1983 to 1993 and the sudden decline in 1998 are undocumented, I suspect the decline dovetails with the introduction of personal computers and e-mail to law practice that occurred about that time. Commercial e-mail first became available in the late rg8os, and America Online introduced its own e-mail system in r993, "beginning the large scale adoption of Internet email as a global standard." By 1998 , traditional memoranda were probably in serious trouble.

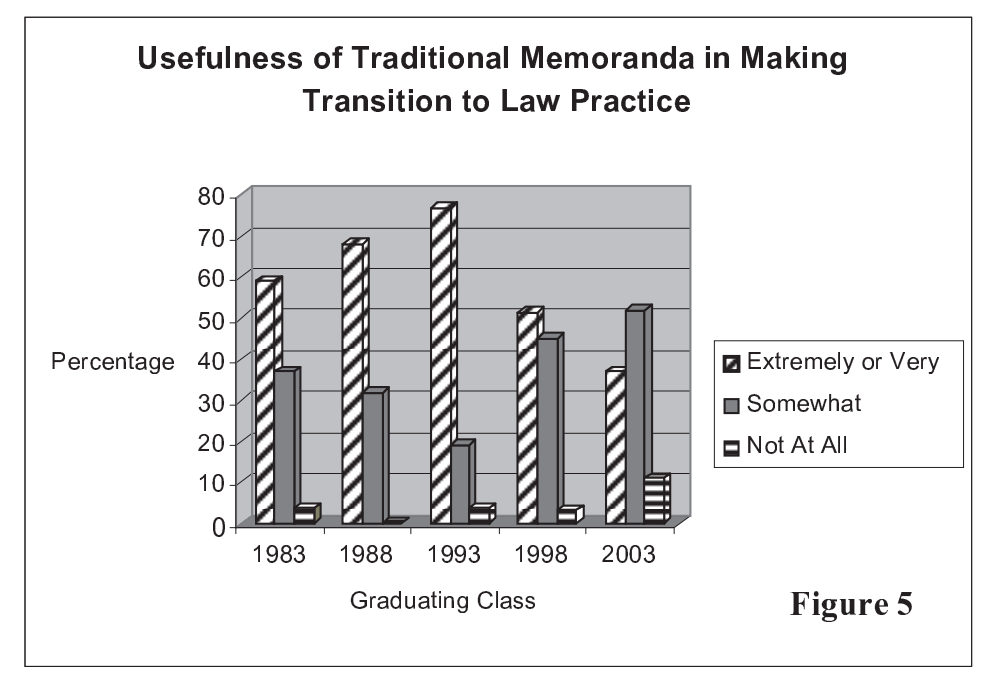

Georgetown Graduates Are Far More Likely to Use Short, Informal Memoranda than Traditional Memoranda and Recommend Teaching This Short Form as an Alternative

Whereas the majority of survey respondents write no traditional memoranda, the largest percentage of graduates estimates writing more than twenty informal memoranda in a given year. ${ }^{17}$

I6. Dave Crocker, E-mail History (1996-2006), available at <http://www.livinginternet.com/e/ ei.htm> (last visited Feb. I4, 2007).

17. See Appendix I, Question I3, at 55 . 


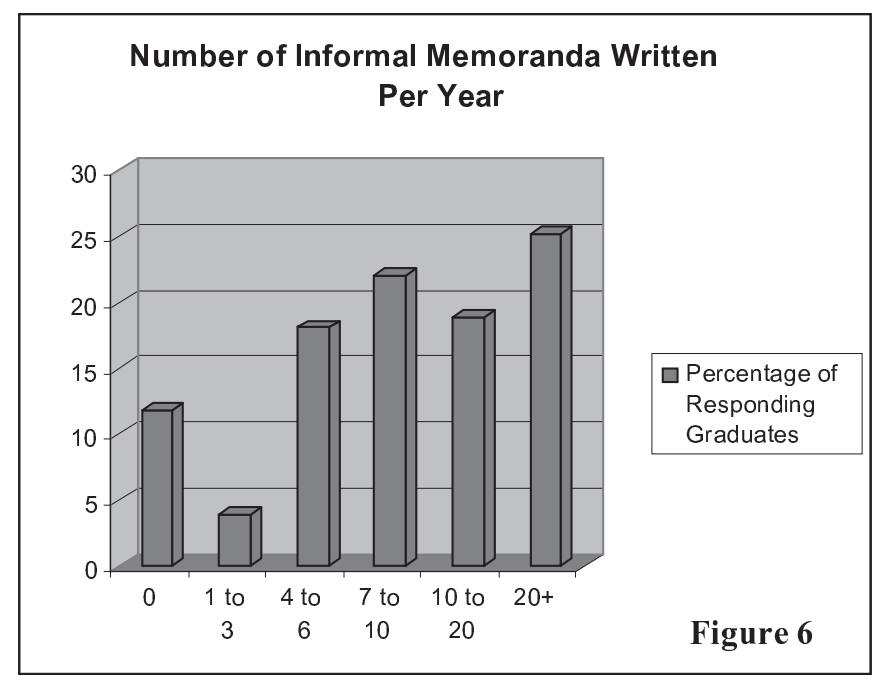

As Figure 7 illustrates, there is no obvious correlation between the number of informal memoranda written and the respondent's graduating class. However, the most recent graduates are writing the most. Thirty-seven percent of 2003 graduates report writing in excess of 20 per year as compared to 9.5 percent of I988 graduates. What is clear is that compared to traditional memoranda, informal memoranda are being written by all graduates in dramatically greater numbers. ${ }^{18}$ (See Figure 8.)

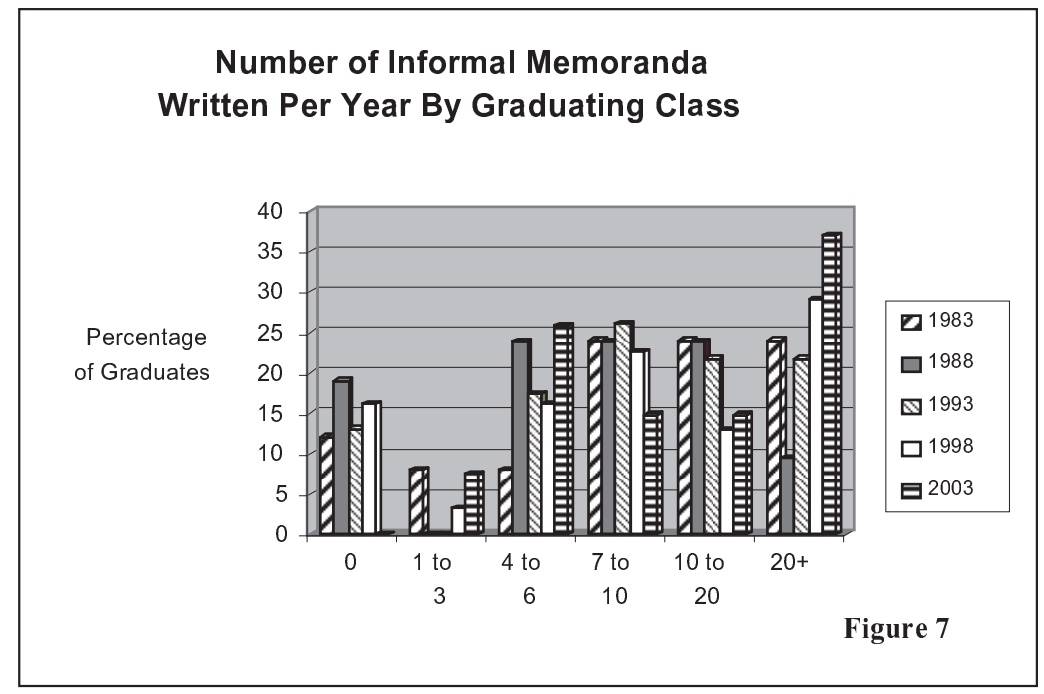

I8. See id. at Questions I3 and I8, at 55, 57 . 


\section{Figure 8}

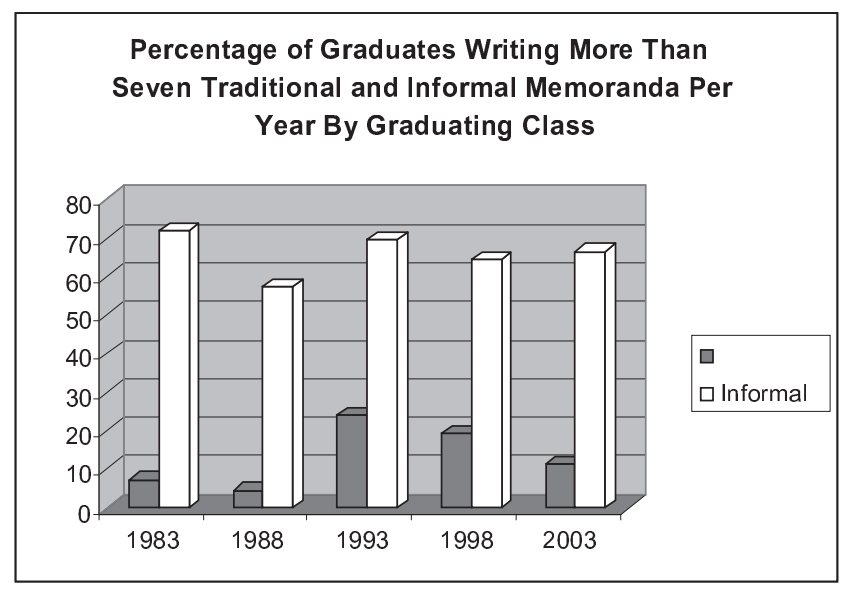

In response to Question ${ }_{17}$, the graduates indicated that the elements of the informal memoranda they use vary, but these memoranda always contain fewer redundant elements than in a traditional memorandum. The largest percentage -36.6 percent-of graduates reported including just a Brief Answer and Discussion section. ${ }^{19}$ (See Figure 9.) In written comments, those graduates who indicated using elements other than those specified said they might use just a brief introduction and discussion section or a question presented, options, and recommendation section.

Question 12 asked what documents, in addition to traditional memoranda, would have been useful in law school for learning to write objective legal analysis. Seventy-six percent of respondents indicated that teaching an informal memorandum format would be useful. ${ }^{20}$ As these graduates suggest, teaching flexible forms of informal memoranda would reflect the reality of contemporary practice. As discussed below, teaching the short form memorandum would also mirror the substantive e-mail, which is by far the most popular method for advising clients. Students would also be prepared to communicate through substantive e-mail as well as informal memoranda. Interestingly, in response to this question, $5^{6.7}$ percent said that client letters should be taught, 47.2 percent said objective analysis in e-mail form should be taught, and 23.8 percent suggested other forms of objective legal writing be taught, such as bench memoranda, opinions, case status letters, and letters to opposing counsel. ${ }^{21}$

\footnotetext{
19. See id. at Question 17 , at 57 .

20. See $i d$. at Question I2, at 54 .

2I. See id.
} 


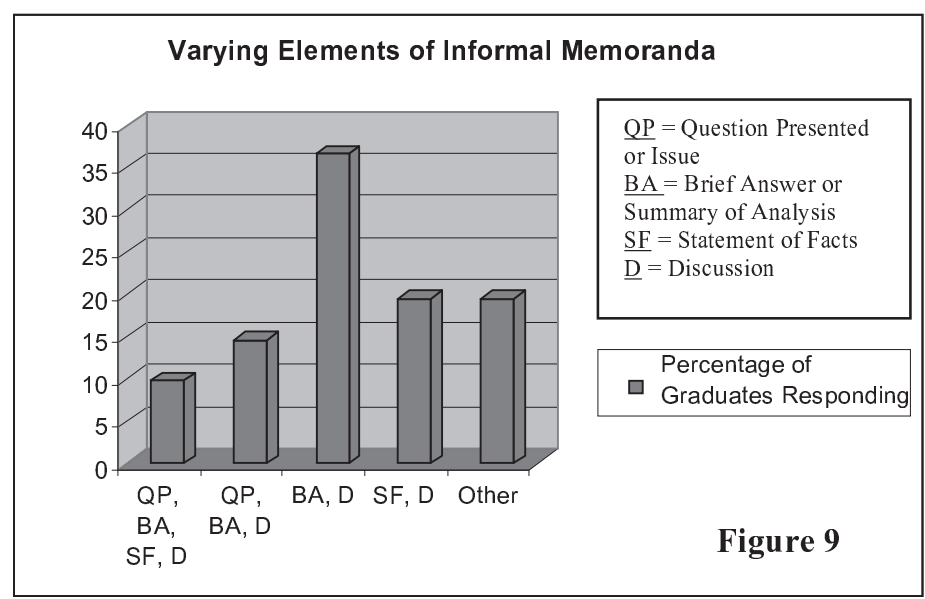

Georgetown Graduates Are Even More Likely to Use E-mail than Informal Memoranda and Recommend Teaching Students about Its Use and Pitfalls in Practice

Even with the more frequent use of informal memoranda as compared to traditional memoranda, Georgetown graduates are far more likely to inform and advise clients by e-mail. Only 2.3 percent of respondents said they always use written memoranda-either traditional or informal-to inform clients about the results of their research. ${ }^{22}$ As Figure io illustrates, the majority of respondents-56.I percent-use written memoranda only sometimes.

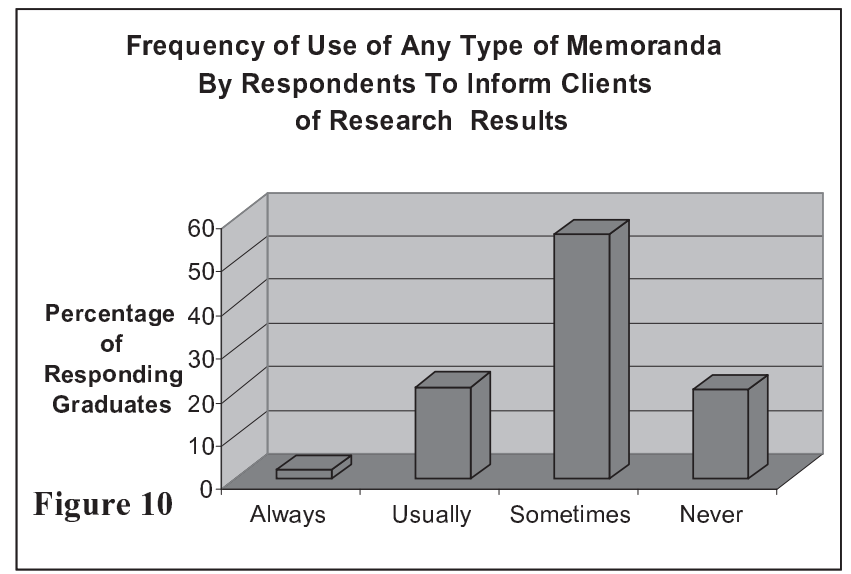

22. See id. at Question 20, at $5^{8}$. 
Figure II demonstrates that the frequency of use is not affected by graduating class; by far, the largest percentage of respondents from each class indicated they use memoranda only sometimes, as opposed to always, usually, or never.

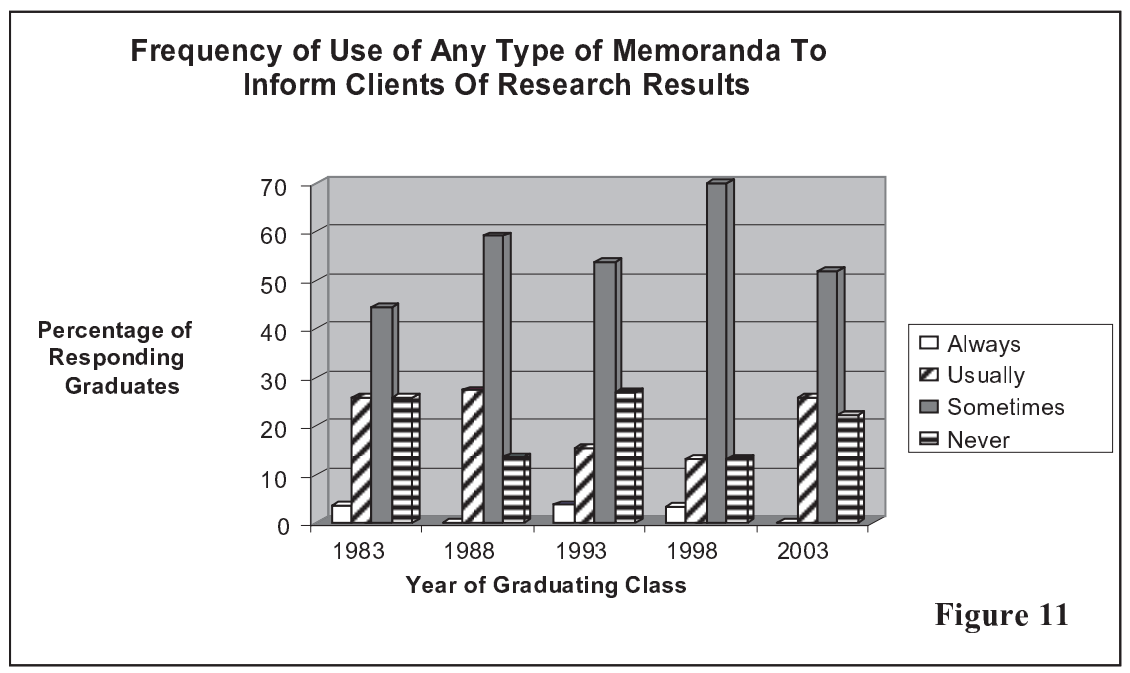

Question 2I asked graduates to identify other methods they use to communicate with clients. Ninety-two percent of the graduates indicated they use "substantive e-mail," defined as a message containing substantive information and not serving simply to forward an attachment. ${ }^{23}$ In response to Question 22, graduates ranked up to eight methods they use to communicate research results to their clients in order of most to least use. As Figure 12 illustrates, 44 percent of the respondents indicated that they use e-mail most often, in contrast to the 4 percent who use traditional memoranda most often. As for the remaining methods of communication, respondents ranked them in the following order: telephone, in person, informal memorandum, letter, and then voice mail. Other methods of communication (including video conferences, draft pleadings, and oral decisions in court) and traditional memoranda came in eighth-the method least preferred. ${ }^{24}$

23. See $i d$. at Question 2I, at 59 .

24. See id. at Question 22, at 59. 


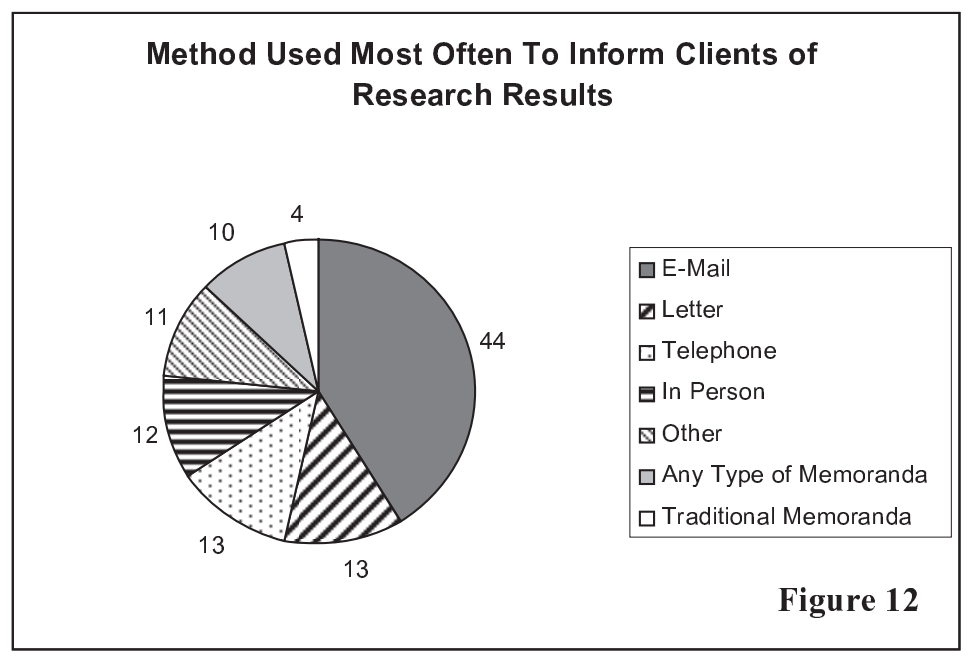

The e-mail format respondents use differs, but its goal is the same: simplicity. E-mail gives respondents the flexibility to compose their messages based on the particular issues presented and not some predetermined format. ${ }^{25}$ One respondent said, "The format used varies and is tailored to the end user and the issue or issues at hand." Another wrote, "Unlike a legal memo [the e-mail] will tend to be organized around the question itself. In other words, the sections are dictated by the substance of the question and not a prescribed formula." Although a few respondents indicated their e-mail looks like a traditional memorandum, ${ }^{26}$ the bulk are more concise and informal. Georgetown graduates who use e-mail to advise clients tend to begin with either the issue and/or their recommendation and follow with their legal analysis. Graduates describe these e-mails as looking either like an informal memorandum, ${ }^{27}$ often with headings, or a letter. ${ }^{28}$ Those graduates who ranked substantive e-mail as one of their top three methods for communicating with clients said the following with regard to the format of their e-mails:

\section{Looks Like an Informal Memorandum}

- "Topic headings, followed by discussion/conclusions."

- "Generally, I write an answer up front and then explain the reasoning."

- "It simply introduces the issue...and discusses black-letter rules,

25. Open-Ended Results Detail, Question 23, Responses 7, I2, 22, 24-25, 27, 57, 75, 89, and I04 (on file with author).

26. Id. at Responses 2 and 20.

27. Id. at Responses I, 3, 6-9, I2-г 4, I6-г9, 24, 26-27, 30-33, 35-37, 40-42, 44-46, 49-6r, 64, 67-77, 8о$84,86,88$, and 9o-97.

28. Id. at Responses 5, I2, 23, 28, 34, 43, 48, 63, 65-66, 78-79, 85, 98-гоо. 
without too much discussion of the facts/rationales of precedential cases."

- "My e-mails usually start with a brief statement of the question... and the relevant facts. Sometimes I also include a sentence indicating what I did to find the answer. The focus is on the conclusion, with brief supporting analysis."

- "It is multi-paragraph, sometimes with headings, for example, Procedural Status, Merits, Next Steps.

- "[B]egin with a restatement of the client's question and the relevant facts, then move to a brief answer and discussion/analysis. When printed, it looks like a memorandum, but lacks the overt structure of a formal legal memo."

\section{Looks Like a Letter}

- "Sometimes a letter format; sometimes a few headings and parts. Depends on complexity."

- "It looks like an e-mail or a letter. If I am inclined to write something more formal, I will format it as a memo and send it as an attachment."

- "The e-mail usually looks like a client letter. It starts with a salutation and goes from there."

- "Not formal. Looks like a letter."

- "My e-mails read like a letter. 'We investigated whether the communication constituted 'fraud' under Texas law.' I then give the answer and a brief analysis."

- "The e-mail looks a lot like a letter."

- "It looks like a business letter."

- "Looks more like the body of a letter would look."

Not surprisingly, a significant number of respondents recommended teaching the use of informal memoranda, client letters, and substantive e-mail in law school and in that order of preference. ${ }^{29}$ (See Figure 13.) Although 47 percent thought it would be useful to teach the use of substantive e-mail, a majority thought it also useful to teach informal memoranda (76 percent) and client letters (57 percent). With regard to teaching the use of substantive e-mail, several graduates indicated the need to teach the dangers inherent in using this relatively new mode of communication. Although e-mail is by nature informal, students should not "perceive it as a more casual form of communication than a memo to another attorney. It isn't... . E-mails with research findings need a beginning, middle and end so that they make sense for posterity." $3^{\circ}$ Another graduate warned: 
If e-mail is to be formally taught, I do think it's important to realize that e-mail to clients is very different from e-mail to friends. It will be taken as a formal statement of your conclusion just as a memo would be. To the extent it's not a complete explanation of the analysis, I think it's important to specify what is being left out. Most importantly, the e-mail should be well-written and proofed just as any other memo would be. I also think it's important to remember how easily e-mails can be forwarded. I've definitely had people at client companies other than the person to whom I sent an e-mail call me to talk about it. $3^{\mathrm{T}}$

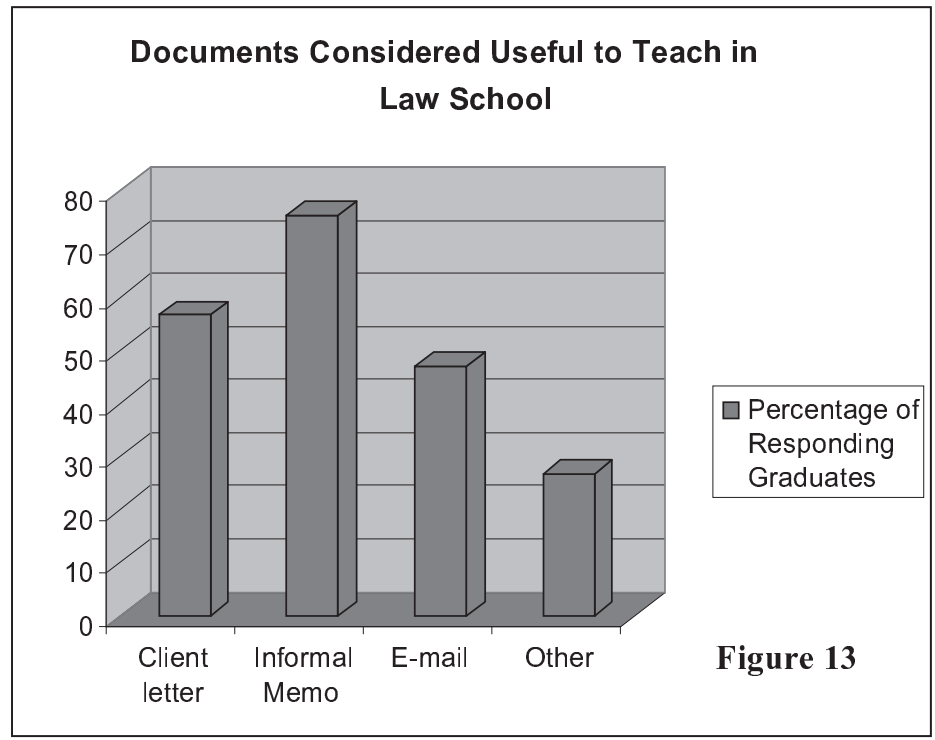

Although relatively few graduates actually write traditional memoranda in practice, the majority who responded-59 percent-indicated either that there was no better way to teach objective legal analysis or that the mode of composition chosen to teach it did not matter..$^{32}$ Very few graduates explicitly recommended that LRW courses abandon teaching traditional memoranda altogether in the first-year curriculum. In response to Question 24, which asked for suggestions with regard to what instruments should be used to teach objective legal analysis, some graduates stated:

- "Students need the basics and then can adapt to informal. Reverse would be difficult."

- "I would suggest focusing on traditional legal memoranda, client letters, and preparation of talking point/outlines that junior attorneys are often asked to prepare."

3. Id. at Response 35 (emphasis added).

32. See Appendix I, Question II, at 54 . 
- "Start with the formal legal memo: at a minimum, it is necessary for communicating with other lawyers and to capture basic research for use in other documents (pleadings, client letters, etc.)."

- "Legal memoranda still do serve a purpose-even if that purpose is mainly to impress the student's firm/agency/non-profit/etc. during his or her $2 \mathrm{~L}$ summer work. First year law students need to understand that in practice the form in a dying breed (few and far between are clients willing to pay for such memoranda). Students would be better prepared for both real-world practice and ${ }_{2} \mathrm{~L}$ summer work if they had more experience with other substantive communication forms (e.g., e-mail, oral presentations, etc.)."

- "I think the memo writing is fine-why not train them in the most formal thing they will have to do-anything else will be easier for them if they know the most rigid and formal."

- "Instruction on the traditional legal memorandum is still imperative in my view because you need to learn what the rules are first before you can judge when it is appropriate to break or modify them."

- "I believe you should continue to instruct with traditional legal memos. In my practice, such memos are not necessarily used to be sent to clients, but to analyze a legal issue for internal purposes, such as formulating legal strategy."

- "The value in teaching the legal memorandum is not in its utility as a tool for communicating with clients!!! The value is in teaching the intellectual discipline and organizational skills necessary to prepare a good one. Those skills, once mastered, are easily transferable to writing letters, e-mails, and even legal briefs and advocacy pieces."

By and large, however, those graduates who strongly support teaching traditional memoranda are not recent graduates. As Figure i4 illustrates, the opinions of graduates from the class of 1983 through 1998 differ greatly from those of 2003 graduates and presumably beyond. Question II asked graduates whether there was a better way to teach students how to formulate common law rules and apply them using case analogies than teaching them to write traditional memoranda. A majority of graduates from the classes of 1983 , I988, 1993, and 1998 indicated either that there was no better way or that it did not matter which mode of composition was used. In contrast, only 35 percent of graduates from the class of 2003 agreed. 33 The majority of these more recent graduates indicated either that there was a better way but they do not know what that is or that there is a better way and they had specific suggestions, such as teaching briefs, informal memoranda, e-mail, and how to give oral advice. One 2003 graduate said:

Not sure that I know the answer, but most of my legal research is communicated by e-mail. It is relatively rare to be asked for a formal memo. Basically, the 
partners want new information, not redundancies in a specific format. As a result, virtually all of my legal research is communicated either orally or by e-mail.

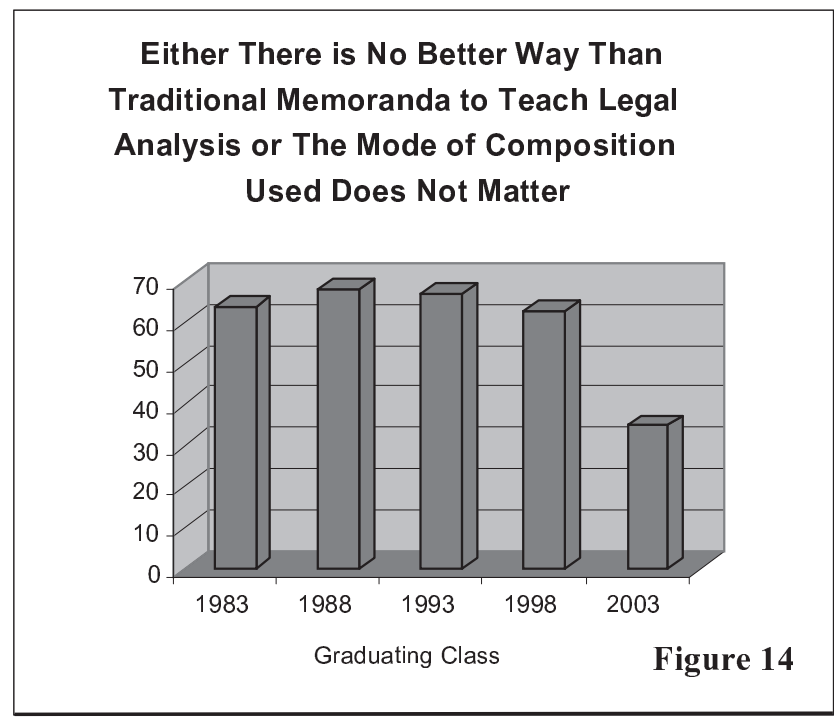

Indeed, graduates from all classes responded to Questions II and 24 by recommending that LRW programs focus less on traditional memoranda and teach additional types of writing such as opinions, motions, client letters, and e-mail. The following comments are representative of their views:

- "Today, most clients prefer more informal communications because the cost of a formal legal memo is quite high."

- " $[\mathrm{Y}]$ ou might consider having students write opinions as if they were the judge in the case. I have often had to write these in cases, and find it very helpful in gaining a total understanding of the law on the issues involved."

- "Less emphasis on the legal memo and more on the client letters, verbal arguments, briefs, excerpted paragraphs, etc."

- "I would suggest focusing on traditional legal memoranda, client letters, and preparation of talking points/outlines that junior attorneys are often asked to prepare for more senior lawyers to use when discussing legal advice with a client, prior to or after providing the client with a written memo of the advice."

- "Interestingly, when I began to practice, I knew how to write a brief or memo to support a motion, but not how to formulate the motion itself. I think it is important to cover what various types of motions look like."

- "More assignments-perhaps weekly-that are brief. For example, most 
of my 'memos' are short e-mails. I haven't written a long memo in years, but I am constantly asked to write one-pagers on issues."

- "I think students should be assigned a case file and have to write various pleadings under time constraints rather than one long legal memorandum for the whole semester."

- "Use a variety. Focus on contract and other drafting skills as well as writing skills."

- "Clients want answers, not dissertations. The formal legal memo is helpful only to present information to another attorney who will distill that information into another format (opinion, brief, letter, or e-mail to client) but is unhelpful to a client, even an attorney. I get them and simply call the lawyer to ask him what it says and to tell him not to bill me for it."

- "Emphasis on effective e-mail writing, effective bullets."

- "I think there needs to be more of a focus on oral communication and honing concise speaking skills."

- "Teaching dangers/limits to e-mail advice is extremely important."

- "Teach drafting e-mail memoranda, but stress the importance of not using e-mail haphazardly to respond to questions. The ease of email's use makes it a valuable resource but also a dangerous one if the responses set forth in it are not well thought out."

\section{Conclusion and Recommendations for First-Year Legal Research and Writing Curricula}

Although legal advice was once sent via snail mail and communicated through traditional memoranda, informal memoranda and substantive e-mails appear to have supplanted them. Seventy-five percent of the Georgetown graduates surveyed report writing no more than three traditional memoranda per year. In contrast, the survey suggests that attorneys are now far more likely to communicate with clients using an informal, more concise, and less expensive format. Forty-four percent of all responding graduates report writing ten or more informal memoranda per year. However, 77 percent report using these informal memoranda only sometimes or never, as opposed to usually or always. Instead, graduates use more direct methods to advise clients, such as e-mail, telephone, or personal contact. Substantive e-mail ranks first as the graduates' preferred method for communicating research results and advice to clients. Eighty percent of the respondents ranked e-mail as one of their top three choices.

Without feeling constrained by a prescribed format, attorneys seem better able to tailor their legal advice to the issue at hand and accommodate their clients' desires for a concise and straightforward answer. Both informal memoranda and substantive e-mail are more direct and less redundant than traditional memoranda. Generally, they begin with a statement of the issue or 
a recommendation, followed by the attorney's analysis, which may or may not be divided into headings. Rarely, it seems, do they include a separate brief answer, facts, or conclusion section. Those graduates who use substantive e-mail to communicate with their clients describe the form of their e-mail as similar either to an informal memorandum or the body of a typical e-mail message or letter.

The shift from traditional to informal memoranda and e-mail should be recognized by legal educators who seek to prepare students for the practice of law. Although traditional memoranda are a "dying breed," few graduates explicitly recommended eliminating the use of the traditional memoranda altogether in LRW courses. In these graduates' minds, the benefits of learning to draft a "soup to nuts" memorandum seem to outweigh the costs, because students are then able to adapt the traditional memorandum format to their particular practice needs. The survey indicates, however, that there is reason to suspect a growing dissatisfaction among more recent Georgetown graduates with the usefulness of learning traditional memoranda. This trend should not be ignored in the LRW faculty's process of selecting modes of composition to teach and the context in which they are taught.

Whether or not LRW courses continue to teach objective legal analysis through the traditional memorandum format, the survey suggests that, at a minimum, these courses acknowledge the newer modes of composition being used by practicing attorneys. Short form memoranda and substantive email could be taught concurrently, as more concise and inexpensive forms of communicating advice. Students could be introduced to these in a variety of hypothetical contexts, preparing them for the likelihood that they will be asked to draft advice in one of these formats. With regard to substantive email, students should also be advised not to treat these e-mails as casual correspondence. As several graduates noted, e-mail to clients still constitutes legal advice and should be carefully proofread and checked for accuracy. Moreover, e-mail can be forwarded at the touch of a button, making it easy to inadvertently violate attorney-client privilege and/or confidentiality.

When LRW faculty choose for good reasons to continue teaching the traditional memorandum, they should emphasize that they are more heuristic than realistic. Although I inform my students in the fall semester that the traditional memorandum format is by no means universal, I did not know just how much its use had waned until I conducted this survey. I recently shared the results with some of my students who are rising 2 Ls. They were shocked just several months later to learn that so few traditional memoranda are actually used in practice. The effect of using traditional memoranda or any other mode of composition on student expectations in the workplace could not have been demonstrated more powerfully. 


\section{Appendix I}

Survey on the Use of Traditional Legal Memoranda In Law Practice

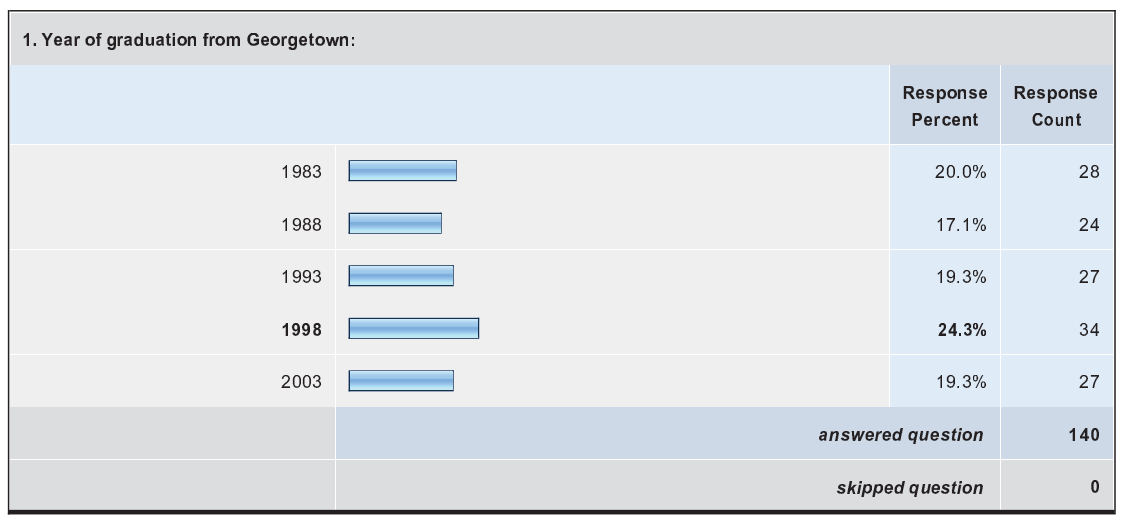

2. Current Title/Position:
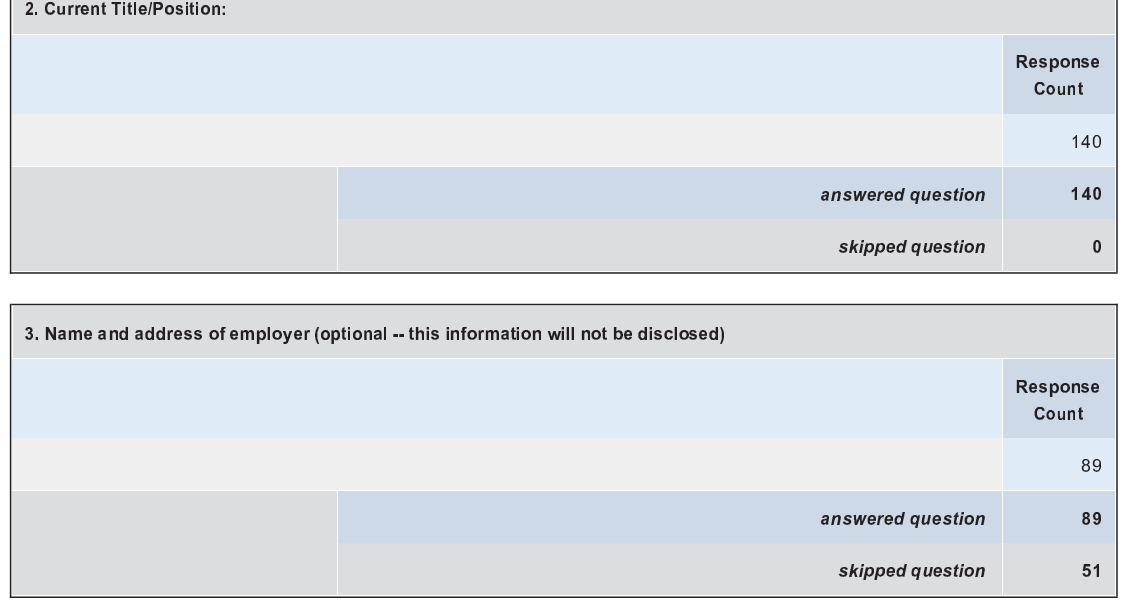
From Snail Mail to E-Mail

\begin{tabular}{|c|c|c|c|}
\hline \multicolumn{4}{|l|}{ 4. Nature of employer } \\
\hline & & $\begin{array}{l}\text { Response } \\
\text { Percent }\end{array}$ & $\begin{array}{l}\text { Response } \\
\text { Count }\end{array}$ \\
\hline a. Private law firm & $\square$ & $69.3 \%$ & 97 \\
\hline b. Corporation & $\square$ & $13.6 \%$ & 19 \\
\hline c. Trade Association & ] & $0.7 \%$ & 1 \\
\hline $\begin{array}{l}\text { d. Government office related to } \\
\text { criminal prosecutions }\end{array}$ & $\square$ & $4.3 \%$ & 6 \\
\hline $\begin{array}{l}\text { e. Government office not related to } \\
\text { criminal prosecutions (i.e., agency) }\end{array}$ & $\square$ & $5.0 \%$ & 7 \\
\hline f. Other (please specify) & $\square$ & $7.1 \%$ & 10 \\
\hline \multicolumn{3}{|c|}{ answered question } & 140 \\
\hline \multicolumn{3}{|c|}{ skipped question } & 0 \\
\hline
\end{tabular}

\begin{tabular}{|c|c|c|c|}
\hline & & $\begin{array}{c}\text { Response } \\
\text { Percent }\end{array}$ & $\begin{array}{c}\text { Response } \\
\text { Count }\end{array}$ \\
\hline $\begin{array}{l}\text { a. Administrative Law and } \\
\text { Regulatory Practice }\end{array}$ & $\square$ & $15.2 \%$ & 21 \\
\hline b. Business Law & $\square$ & $26.1 \%$ & 36 \\
\hline c. Entertainment & $\square$ & $3.6 \%$ & 5 \\
\hline d. Environmental Law & $\square$ & $5.1 \%$ & 7 \\
\hline e. Family Law & 日 & $2.9 \%$ & 4 \\
\hline f. General Practice & $\square$ & $7.2 \%$ & 10 \\
\hline g. Government/Public Sector & $\square$ & $8.7 \%$ & 12 \\
\hline h. Health Law & $\square$ & $3.6 \%$ & 5 \\
\hline i. Intellectual Property & $\square$ & $11.6 \%$ & 16 \\
\hline j. International Law & $\square$ & $7.2 \%$ & 10 \\
\hline k. Labor/Employment Law & $\square$ & $12.3 \%$ & 17 \\
\hline I. Legislative & $\square$ & $4.3 \%$ & 6 \\
\hline
\end{tabular}




\begin{tabular}{|r|r|r|r|}
\hline m. Litigation & & $\mathbf{4 7 . 1 \%}$ & 65 \\
\hline n. Public Contract Law & - & $1.4 \%$ & 2 \\
\hline o. Real Estate & $\square$ & $9.4 \%$ & 13 \\
\hline p. Tax: & $\square$ & $3.6 \%$ & 5 \\
\hline q. Other (please specify) & & answered question & $\mathbf{1 3 8}$ \\
\hline & & skipped question & $\mathbf{2}$ \\
\hline
\end{tabular}

\begin{tabular}{|c|c|c|c|}
\hline & & $\begin{array}{c}\text { Response } \\
\text { Percent }\end{array}$ & $\begin{array}{c}\text { Response } \\
\text { Count }\end{array}$ \\
\hline a. $1-25$ & $\square$ & $26.4 \%$ & 37 \\
\hline b. $25-50$ & $\square$ & $8.6 \%$ & 12 \\
\hline c. $50-100$ & $\square$ & $12.1 \%$ & 17 \\
\hline d. $100-150$ & $\square$ & $2.9 \%$ & 4 \\
\hline e. $150-200$ & $\square$ & $6.4 \%$ & 9 \\
\hline \multirow{3}{*}{ f. $200+$} & 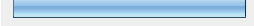 & $43.6 \%$ & 61 \\
\hline & \multicolumn{2}{|c|}{ answered question } & 140 \\
\hline & \multicolumn{2}{|c|}{ skipped question } & 0 \\
\hline
\end{tabular}

7. How long have you been in your current position?

\begin{tabular}{|c|c|c|c|}
\hline & $\begin{array}{c}\text { Response } \\
\text { Average }\end{array}$ & $\begin{array}{c}\text { Response } \\
\text { Total }\end{array}$ & $\begin{array}{c}\text { Response } \\
\text { Count }\end{array}$ \\
\hline years AND & 5.52 & 723 & 131 \\
\hline months & 6.13 & 650 & 106 \\
\hline & \multicolumn{2}{|c|}{ answered question } & 140 \\
\hline & \multicolumn{2}{|c|}{ skipped questio } & 0 \\
\hline
\end{tabular}




\begin{tabular}{|r|r|r|r|}
\hline 8. How long have you been practicing law? & & & \\
\hline \\
years AND & $\begin{array}{c}\text { Response } \\
\text { Average }\end{array}$ & $\begin{array}{c}\text { Response } \\
\text { Total }\end{array}$ & $\begin{array}{c}\text { Response } \\
\text { Count }\end{array}$ \\
\hline months & 11.60 & 1601 & 138 \\
\hline & 7.08 & 545 & 77 \\
\hline
\end{tabular}

\begin{tabular}{|c|c|c|c|}
\hline & & $\begin{array}{c}\text { Response } \\
\text { Percent }\end{array}$ & $\begin{array}{c}\text { Response } \\
\text { Count }\end{array}$ \\
\hline a. Extremely & $\square$ & $39.8 \%$ & 53 \\
\hline b. Very & $L^{-}$ & $35.3 \%$ & 47 \\
\hline c. Somewhat & $\square$ & $24.1 \%$ & 32 \\
\hline d. Not at all & ] & $0.8 \%$ & 1 \\
\hline \multicolumn{3}{|c|}{ answered question } & 133 \\
\hline \multicolumn{3}{|c|}{ skipped question } & 7 \\
\hline
\end{tabular}

\begin{tabular}{|c|c|c|c|}
\hline & & $\begin{array}{c}\text { Response } \\
\text { Percent }\end{array}$ & $\begin{array}{c}\text { Response } \\
\text { Count }\end{array}$ \\
\hline a. Extremely & $\square$ & $21.8 \%$ & 29 \\
\hline b. Very & $\square$ & $36.1 \%$ & 48 \\
\hline c. Somewhat & 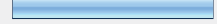 & $37.6 \%$ & 50 \\
\hline d. Not at all & $\square$ & $4.5 \%$ & 6 \\
\hline \multicolumn{3}{|c|}{ answered question } & 133 \\
\hline \multicolumn{3}{|c|}{ skipped question } & 7 \\
\hline
\end{tabular}



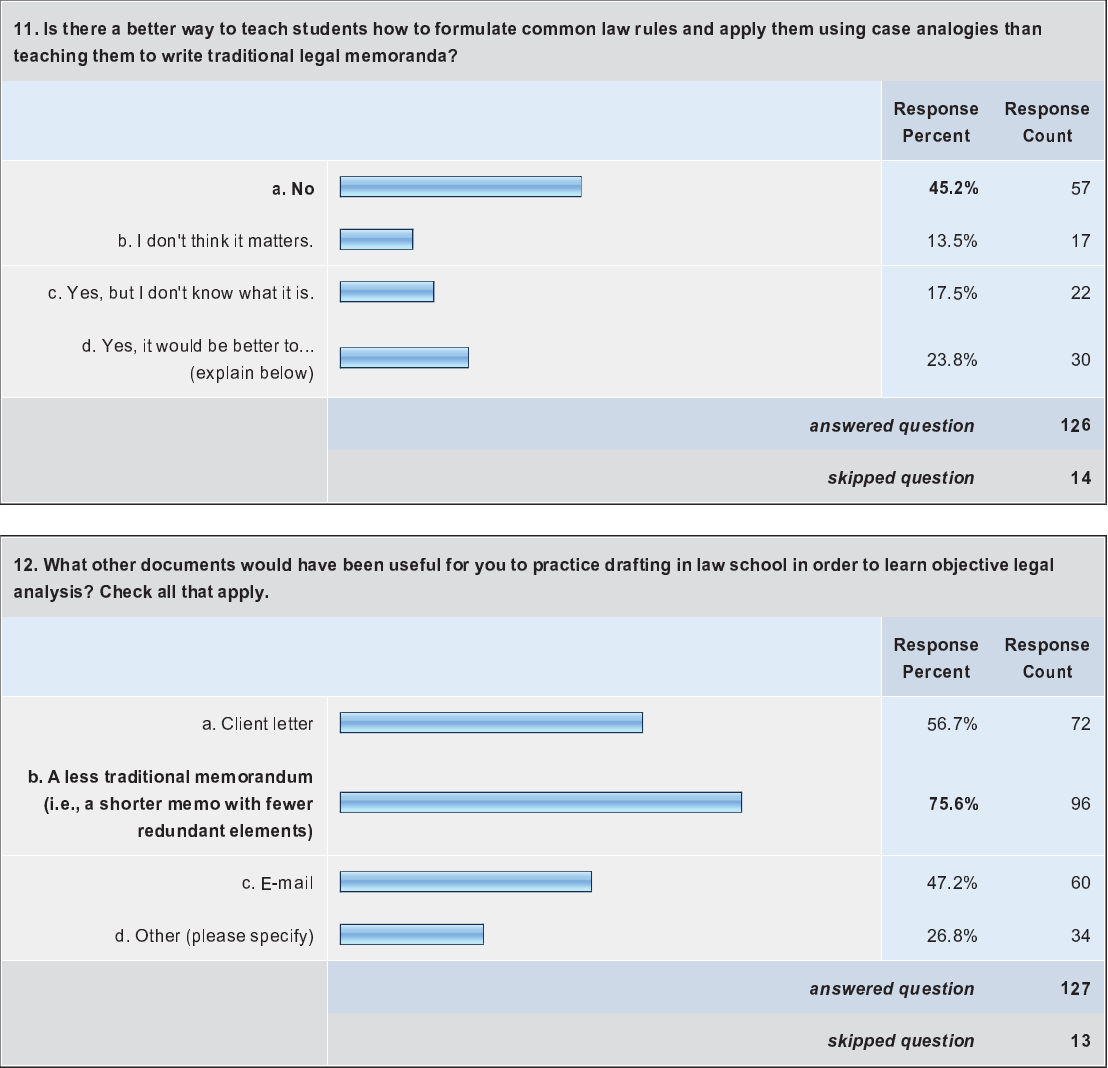


\begin{tabular}{|c|c|c|c|}
\hline \multicolumn{4}{|c|}{ 13. How many traditional legal memoranda do you write per year? } \\
\hline & & $\begin{array}{c}\text { Response } \\
\text { Percent }\end{array}$ & $\begin{array}{c}\text { Response } \\
\text { Count }\end{array}$ \\
\hline a. 0 & ${ }^{-}$ & $43.5 \%$ & 57 \\
\hline b. $1-3$ & $\square$ & $31.3 \%$ & 41 \\
\hline c. $4-6$ & $\square$ & $11.5 \%$ & 15 \\
\hline d. $7-10$ & $\square$ & $4.6 \%$ & 6 \\
\hline e. $10-20$ & $\square$ & $5.3 \%$ & 7 \\
\hline f. $20+$ & $\square$ & $3.8 \%$ & 5 \\
\hline \multicolumn{3}{|c|}{ answered question } & 131 \\
\hline \multicolumn{3}{|c|}{ skipped question } & 9 \\
\hline
\end{tabular}

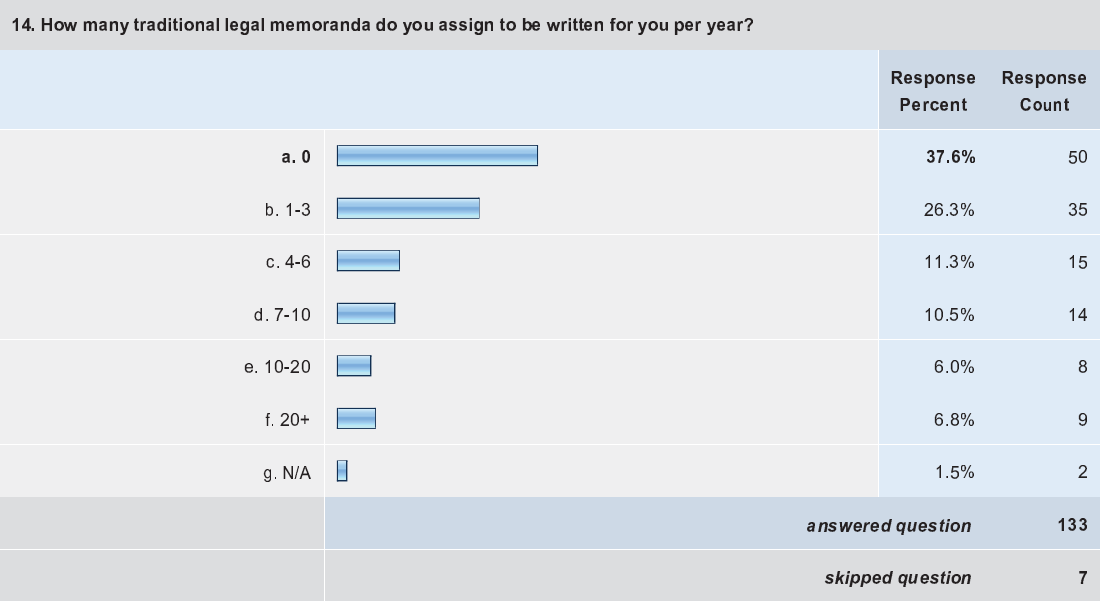




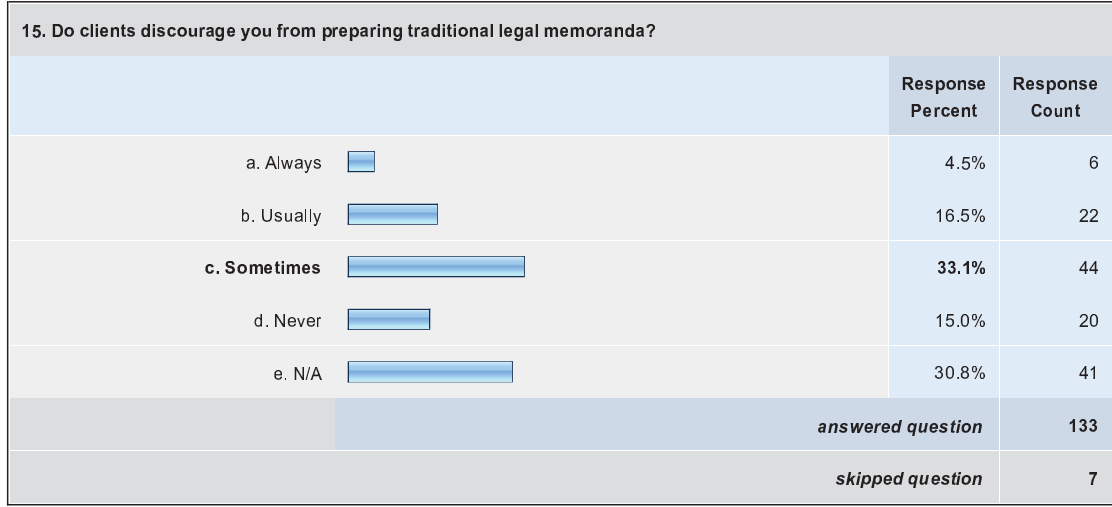

16. If your answer to question 15 was $a, b$, or $c$, why do clients discourage you from preparing traditional legal memoranda? Check all that apply.

\begin{tabular}{|c|c|c|c|}
\hline & & $\begin{array}{c}\text { Response } \\
\text { Percent }\end{array}$ & $\begin{array}{l}\text { Response } \\
\text { Count }\end{array}$ \\
\hline a. Too expensive & $L^{-}$ & $78.0 \%$ & 64 \\
\hline b. Not that useful & ${ }^{-}$ & $47.6 \%$ & 39 \\
\hline $\begin{array}{l}\text { c. It is more efficient just to draft the } \\
\text { persuasive piece, contract, or other } \\
\text { document that the memo anticipates }\end{array}$ & 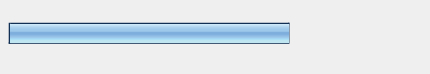 & $52.4 \%$ & 43 \\
\hline d. Other reason (please specify) & 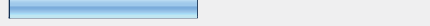 & $35.4 \%$ & 29 \\
\hline \multicolumn{3}{|c|}{ answered question } & 82 \\
\hline \multicolumn{3}{|c|}{ skipped } & 58 \\
\hline
\end{tabular}




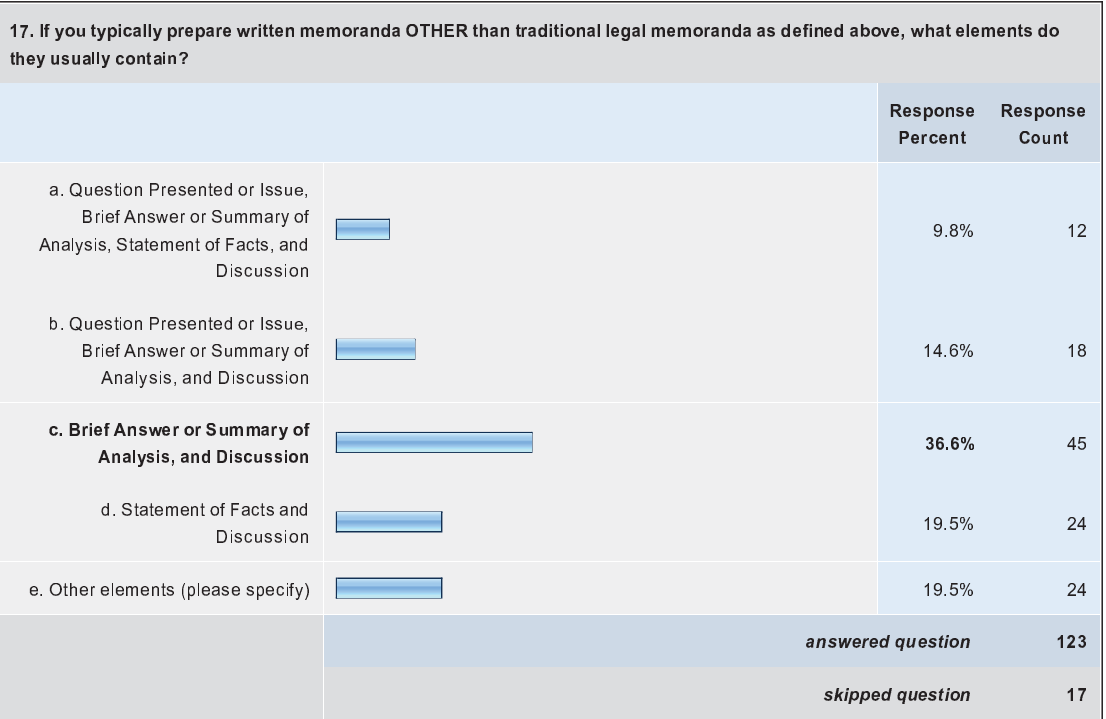

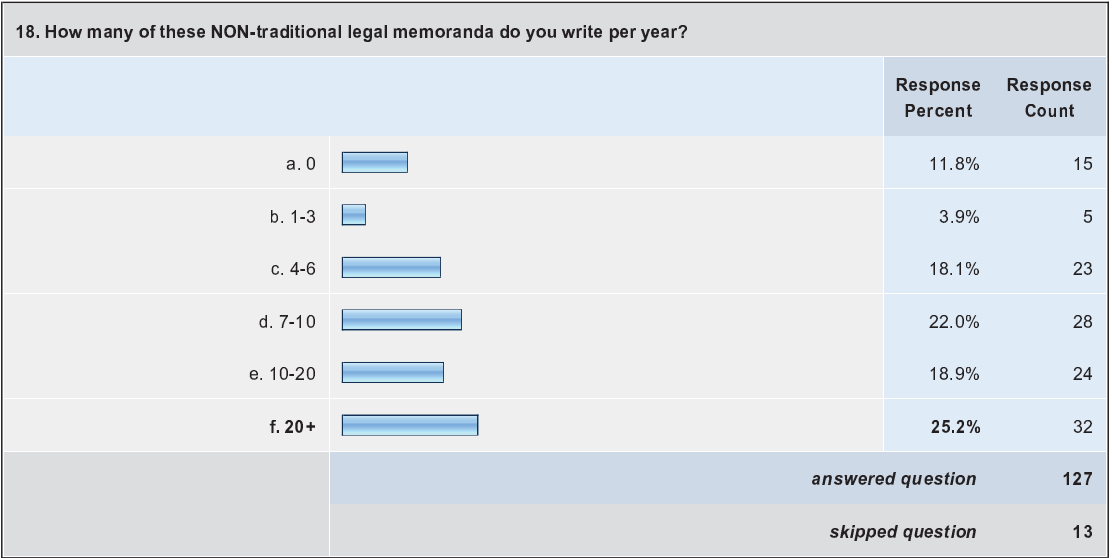




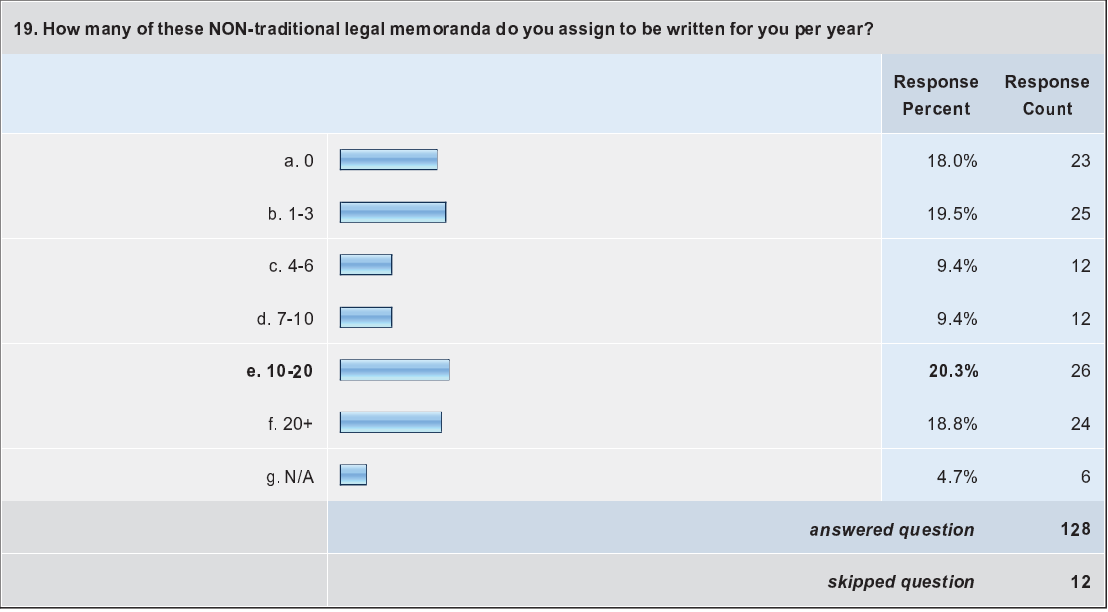

\begin{tabular}{|c|c|c|c|}
\hline & & $\begin{array}{l}\text { Response } \\
\text { Percent }\end{array}$ & $\begin{array}{c}\text { Response } \\
\text { Count }\end{array}$ \\
\hline a. Always & 日 & $2.3 \%$ & 3 \\
\hline b. Usually & $\square$ & $21.2 \%$ & 28 \\
\hline c. Sometimes & $\square$ & $56.1 \%$ & 74 \\
\hline d. Never & $\square$ & $20.5 \%$ & 27 \\
\hline & \multicolumn{2}{|c|}{ answered question } & 132 \\
\hline & \multicolumn{2}{|c|}{ skipped question } & 8 \\
\hline
\end{tabular}




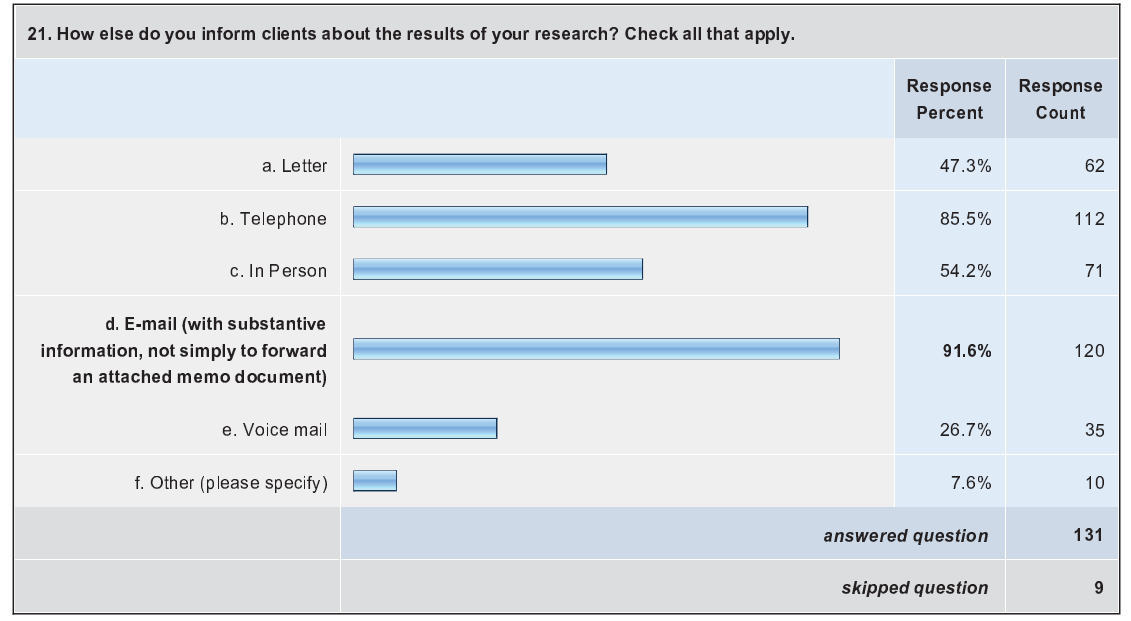

\begin{tabular}{|c|c|c|c|c|c|c|c|c|c|c|}
\hline & 1 & 2 & 3 & 4 & 5 & 6 & 7 & 8 & $\begin{array}{l}\text { Rating } \\
\text { Average }\end{array}$ & $\begin{array}{r}\text { Respo } \\
\text { Cou }\end{array}$ \\
\hline a. Traditional legal memorandum & $\begin{array}{c}4.0 \% \\
(4)\end{array}$ & $\begin{array}{c}8.0 \% \\
(8)\end{array}$ & $\begin{array}{c}7.0 \% \\
(7)\end{array}$ & $\begin{array}{c}10.0 \% \\
(10)\end{array}$ & $\begin{array}{c}12.0 \% \\
(12)\end{array}$ & $\begin{array}{c}20.0 \% \\
(20)\end{array}$ & $\begin{array}{c}16.0 \% \\
(16)\end{array}$ & $\begin{array}{c}23.0 \% \\
(23)\end{array}$ & 5.57 & \\
\hline \multirow[t]{2}{*}{$\begin{array}{r}\text { b. Any other type of legal } \\
\text { memorandum, as described in } \\
\text { Question } 16\end{array}$} & $\begin{array}{c}9.7 \% \\
(11)\end{array}$ & $\begin{array}{c}15.0 \% \\
(17)\end{array}$ & $\begin{array}{c}15.0 \% \\
(17)\end{array}$ & $\begin{array}{c}18.6 \% \\
(21)\end{array}$ & $\begin{array}{c}13.3 \% \\
(15)\end{array}$ & $\begin{array}{c}13.3 \% \\
(15)\end{array}$ & $\begin{array}{c}12.4 \% \\
(14)\end{array}$ & $\begin{array}{c}2.7 \% \\
(3)\end{array}$ & 4.13 & \\
\hline & $\begin{array}{c}12.6 \% \\
(14)\end{array}$ & $\begin{array}{c}9.0 \% \\
(10)\end{array}$ & $\begin{array}{c}16.2 \% \\
(18)\end{array}$ & $\begin{array}{c}14.4 \% \\
(16)\end{array}$ & $\begin{array}{c}13.5 \% \\
(15)\end{array}$ & $\begin{array}{c}21.6 \% \\
(24)\end{array}$ & $\begin{array}{c}7.2 \% \\
(8)\end{array}$ & $\begin{array}{c}5.4 \% \\
(6)\end{array}$ & 4.28 & \\
\hline d. Telephone & $\begin{array}{c}12.7 \% \\
(14)\end{array}$ & $\begin{array}{c}28.2 \% \\
(31)\end{array}$ & $\begin{array}{c}22.7 \% \\
(25)\end{array}$ & $\begin{array}{c}18.2 \% \\
(20)\end{array}$ & $\begin{array}{c}7.3 \% \\
(8)\end{array}$ & $\begin{array}{c}3.6 \% \\
(4)\end{array}$ & $\begin{array}{l}5.5 \% \\
(6)\end{array}$ & $\begin{array}{c}1.8 \% \\
(2)\end{array}$ & 3.21 & \\
\hline e. In person & $\begin{array}{c}12.3 \% \\
(14)\end{array}$ & $\begin{array}{c}16.7 \% \\
(19)\end{array}$ & $\begin{array}{c}12.3 \% \\
(14)\end{array}$ & $\begin{array}{c}21.1 \% \\
(24)\end{array}$ & $\begin{array}{c}16.7 \% \\
(19)\end{array}$ & $\begin{array}{c}9.6 \% \\
(11)\end{array}$ & $\begin{array}{c}7.0 \% \\
(8)\end{array}$ & $\begin{array}{c}4.4 \% \\
(5)\end{array}$ & 3.92 & \\
\hline f. Substantive e-mail & $\begin{array}{c}43.9 \% \\
(54)\end{array}$ & $\begin{array}{c}23.6 \% \\
(29)\end{array}$ & $\begin{array}{c}12.2 \% \\
(15)\end{array}$ & $\begin{array}{c}7.3 \% \\
(9)\end{array}$ & $\begin{array}{c}2.4 \% \\
(3)\end{array}$ & $\begin{array}{c}0.8 \% \\
\text { (1) }\end{array}$ & $\begin{array}{c}4.1 \% \\
(5)\end{array}$ & $\begin{array}{c}5.7 \% \\
(7)\end{array}$ & 2.48 & \\
\hline g. Voice mail & $\begin{array}{l}1.0 \% \\
(1)\end{array}$ & $\begin{array}{c}3.8 \% \\
(4)\end{array}$ & $\begin{array}{c}18.3 \% \\
(19)\end{array}$ & $\begin{array}{c}11.5 \% \\
(12)\end{array}$ & $\begin{array}{c}15.4 \% \\
(16)\end{array}$ & $\begin{array}{c}15.4 \% \\
(16)\end{array}$ & $\begin{array}{c}22.1 \% \\
(23)\end{array}$ & $\begin{array}{c}12.5 \% \\
(13)\end{array}$ & 5.34 & \\
\hline & $10.5^{\circ}$ & $1.8 \%$ & $1.8 \%$ & $3.5 \%$ & $8.8 \%$ & $7.0 \%$ & $19.3 \%$ & $47.4 \%$ & & \\
\hline
\end{tabular}




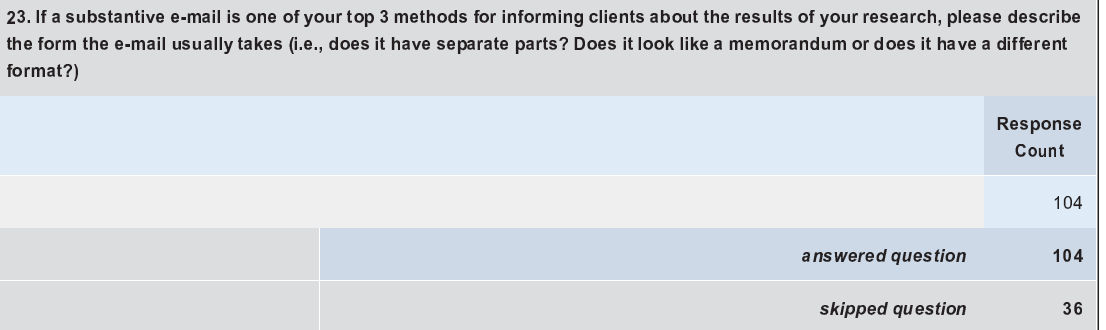

24. What suggestions do you have for Georgetown's legal writing faculty in terms of the instruments that should be used to teach objective legal an alysis in the first year of law school?

\begin{tabular}{|l|r|r|}
\hline & \multicolumn{2}{c|}{$\begin{array}{c}\text { Response } \\
\text { Count }\end{array}$} \\
\hline & answered question & 91 \\
\hline & skipped question & 49 \\
\hline
\end{tabular}

